\title{
Economic, Social and Environmental Impacts of Fuel Subsidies:
}

\section{A Revisit of Malaysia}

\author{
Yingzhu Li ${ }^{\text {a, }}$, Xunpeng Shi ${ }^{\text {a,b }}$, Bin $\mathrm{Su}^{\text {a }}$ \\ a. Energy Studies Institute, National University of Singapore, Singapore \\ b. University of Technology Sydney, Australia-China Relations Institute, Australia
}

\begin{abstract}
Subsidizing energy has been widely used but is economically unfavorable. The Malaysian government has shown strong intention to reduce energy subsidies recently, but face challenges to prepare policy instruments to manage the impact. This study develops a Computable General Equilibrium (CGE) model with breakdown of households by income level to evaluate the potential impacts of removing energy subsidies on the Malaysian economy. It is shown that removing petroleum and gas subsidy would improve economic efficiency and increase GDP up to $0.65 \%$. Budget deficit would be largely reduced after removing the petroleum subsidies, especially when the saved subsidy cost is not budgeted for other expenditure. Households would be worse off in most scenarios due to higher price level, but some compensation policy could make the lowest income group no worse than baseline, without harm the economy. The reduction in carbon emissions ranges $1.84-6.63 \%$ in different scenarios. The simulation results suggest Malaysia to completely remove all fuel subsidies and use the saved funding to cut budget deficit or spend on education, health and other service sector. It is also necessary to set a compensation scheme to minimize public resistance and make sure such scheme is affordable.
\end{abstract}

Key words: CGE model; Fuel subsidy reform; Household; Carbon emissions; Malaysia JEL Classification: C68, E27, Q43, Q58

\footnotetext{
* Corresponding author. Tel.: (+65) 6516-6706 Fax: (+65) 6775-1831

Email address: li.yingzhu@ @us.edu.sg
} 


\section{Introduction}

Subsidy has been an important energy policy instrument in many countries due to social and political concerns, but is widely deemed as economically unfavorable. Although different in form, energy subsidies generally work by directly or indirectly lowering the net amount paid by energy consumers or raising the effective price received by energy producers (IEA, 1999). Subsidies to energy products make consumers lack incentive to conserve energy, as the subsidized energy prices cannot reflect the true costs of energy supply and disclose adequate information of resource scarcity. Subsidies to energy producers also hamper their efforts to optimize production and adopt more advanced technologies. Over-use of energy caused by both types of subsidies would accelerate the depletion of fossil resources and aggravate environmental degradation (e.g. climate change, acid rain and air pollution).

From social perspective, as differentiating customers is costly in practice, energy subsidies to households are usually applied to all income groups and may even spill over to industries in practice. Against the original intention of assisting disadvantaged groups, the universal energy subsidy benefits accrue disproportionately to higher income groups as the poor overall consumes much less energy. Over-consumption arising from subsidized prices also tends to increase import demand of net energy importers or reduce exports by net energy exporters, which will deteriorate the country's balance of payments and raise concerns on energy security. These environmental, economic and social concerns have motivated governments and international organizations to vote for removing energy subsidies.

An evolving trend towards no or less energy subsidies originated in OECD countries during the 1990s, and has spread to developing and transmission economies gradually. For developed countries, environmental problems (especially climate change) and the goal for sustainable development are their major motivations to phase out energy subsidies. Since the Rio Earth Summit in 1992, the 
wealthy countries have made great efforts to reduce the distortions in energy markets (OECD, 1997a). On the other hand, economic growth is the primary concern of developing and transmission countries. Usually it is pressure from international community or/and financial burden on fiscal budget that force them to reform energy subsidies.

Particularly, subsidies to fossil fuels are prevailing and serious in the Association of Southeast Asian Nations (ASEAN), which amounted to \$51 billion in 2011 (IEA, 2013). Even so, Malaysia is an outstanding example in the neighborhood. In 2011, the share of after-tax fossil fuel subsidies to GDP was roughly $7.2 \%$ in Malaysia, only less than $8.4 \%$ in Brunei but much higher than the world average of $2.7 \%$ (Clements et al., 2013). In terms of the ratio of energy subsidies to overall government budgets, Malaysia had the highest ratio in ASEAN at about 32.9\%, which was much higher than the world average of $8.1 \%$ (Clements et al., 2013). Estimates show that higher-income groups got more than $70 \%$ of the fuel subsidies in Malaysia (NEAC, 2009). Table 1 gives an overview of Malaysia's subsidy policies for fossil fuels. ${ }^{1}$ Generally, budget for petroleum subsidies in Malaysia has grown substantially overtime since 2000. Gas subsidies provided indirectly by PETRONAS do not explicitly appear on the fiscal budget, but implicitly affects government revenue through reduced corporate tax base. The amount of PETRONAS' forgone revenue is much larger than petroleum subsidies in size.

Malaysian government proposed to gradually rationalize commodity subsidies in the "20102015 Malaysia Plan”, motivated by rising budget deficit and national debt, dwindling current account surplus and currency depreciation partially due to lacking actions to cut budget deficit (IISD, 2014). However, the initial government plans did not succeed, except an ad hoc increase of petroleum price in September 2013 (see Table 1). Only the low oil price at the end of 2014 finally

\footnotetext{
${ }^{1}$ Electricity consumers may receive monthly rebate and even a discount on bills (e.g. government schools and welfare homes). As the amount is small if compared with subsidies to fossil fuels, direct electricity subsidy would not be discussed in this study.
} 
made it possible for Malaysia to overhaul fossil fuel subsidies to some extent (Adam and Pakiam, 2014). But the fundamentals of petroleum subsidy policy has not been changed, and it is not clear whether the fossil fuels subsidies will come back if the oil prices increase again (Shi, 2016). ${ }^{2}$

However, while the majority of citizens may support the subsidy rationalization policy, the rest who are not willing to part with the subsidies may hamper the reform. A poll conducted by the government shows that $61 \%$ of the Malaysian public supported reducing subsidies (IISD, 2013). The 2013 adjustment still incurred fierce oppositions from political parties and the public, and triggered several protests across Malaysia due to corruption concerns and doubts on the government's promises (IISD, 2014). Therefore, it is timely to investigate the economic, social and environmental impacts of different reform schemes, identify the most vulnerable sectors and income groups, and evaluate potential compensation to households. A static computable general equilibrium (CGE) framework is developed based on Malaysia's input-output (I-O) tables to implement the assessment.

Compared to existing studies on energy subsidies in Malaysia, this paper contributes to the literature in the four aspects. First, households are disaggregated into four groups by income so that the differential impacts of fuel subsidy reform on different income groups and compensation policies targeting the poor could be analyzed. Second, in addition to petroleum subsidies that are the major topic in previous studies, natural gas subsidy provided by state-owned gas supplier is also analyzed in this study. Third, different settings are simulated for the use of saved budget or increased tax revenue stemming from subsidy reform, which could provide policy makers a range of potential impacts depending on government behavior. Last, this study uses the recently released Malaysia’s 2010 I-O tables, while previous CGE studies are based on its 2005 or older I-O tables.

\footnotetext{
${ }^{2}$ An Incentive Based Regulation framework for natural gas was scheduled to be introduced in January 2016, but so far no obvious action has been taken or publicized.
} 
The paper proceeds as follows: Section 2 briefly reviews literature on energy subsidies and studies relevant to Malaysia. Section 3 introduces the CGE model and scenario settings. Simulation results and interpretations are reported in Section 4. The last section discusses the policy implications and concludes the paper.

\section{Literature Review}

Although advocated by economists and environmentalists, not all the interest groups support abolishing energy subsidy. Major opponent opinions are that disadvantaged groups would not be able to couple with the market prices of fuels and electricity, and firms would face higher production costs which would be partially passed on to consumers and partially undertaken by the firms. In other words, the general public and also the industries would not support such policy. The debates have been ongoing for decades, and public protests or even riots took place when some countries attempted to revise exiting policies for energy subsidy. For example, when the government raised the petroleum prices by $23 \%$ on February 2006, the public expressed their dissatisfaction and anger through protests (Bacon and Kojima, 2006). Moreover, fuel subsidy removal is also often used as a weapon in domestic politics (Shi and Kimura, 2014).

Along with the years of debates and practices, a large body of research has been conducted to investigate energy subsidy related issues. The research was primarily initiated and has been driven by international organizations such as the United Nations, World Bank, OECD and IEA. Early studies made great efforts in estimating the extent of energy price distortions or the amount of subsidies provided (e.g. Kosmo, 1989; Larsen and Shah, 1992; Koplow, 1993; IEA, 1994 and 1995; Larsen, 1994; Larsen and Shah, 1995). Several metrics, such as the divergence between actual and "undistorted" prices, producer support estimate, consumer support estimate and aggregate measure of support, have been developed to measure different types of energy subsidies (Porter, 2002). 
With the implementation of energy subsidy reform over the world, qualitative literature focus on lessons learned from past experience, challenges for reform and the design of optimal strategies for governments to smooth the reform path based on country-specific conditions (e.g. OECD, 1996, 1997b, 1998, 2005 and 2013; IEA and UNEP, 2001; UNEP, 2004 and 2008; World Bank, 2010). Quantitative literature usually uses numerical models to analyze economic, environmental and welfare impacts of energy subsidies (e.g. Burniaux et al., 1992; Light, 1999; Anderson and McKibbin, 2000; OECD, 2000; Burniaux and Chateau, 2011; Burniaux et al., 2011; Liu and Li, 2011; UNDP, 2012; Acar and Yeldan, 2016; Dennis, 2016; Rentschler, 2016). As the quantitative studies differ in scope, methodology and years of reference, the results obtained are quite diverse and not directly comparable. Among others, CGE modeling- a macroeconomic framework based on general equilibrium theory- is the most common approach adopted to quantify the impacts of subsidy reform. Most quantitative studies at global and regional levels by international organizations and institutes are based on CGE modelling (e.g. OECD, 2013; UNEP, 2014).

Studies on energy subsidies relevant to Malaysia also appeared in the recent literature. IISD (2013) reviewed Malaysia's energy subsidies by fuel type and identified experiences that could be useful to Malaysia from efforts to reform energy subsidies in other countries. IISD (2014) focused on Malaysia's fuel subsidy reform in 2013, and discussed lessons learned from the reform. There are also some quantitative studies using CGE models and Malaysia's 2005 I-O tables. Solaymani and Kari (2014) evaluated the impacts of removing petroleum subsidy and electricity rebate on Malaysia, with a focus on the transportation sector. They show that the outputs of land transport, water transport and air transport would decrease by $3.5 \%, 1.2 \%$ and $2.1 \%$, respectively. Similarly, Solaymani et al. (2015) investigated energy subsidy reform and the resulting change in travel behaviours of rural, urban and noncitizen households. Solaymani et al. (2014) explored the impacts of removing all government subsidies, including those on food, energy and education. It is 
discovered that poverty levels among rural households would increase more significantly than urban households. Solaymani (2016) focused on the poverty and income inequality impacts of energy subsidy reform, and found that urban households would suffer more than rural and noncitizen households.

The several quantitative studies discussed above focus on certain industries or differentiated impacts on household groups by ethnic or residential area. Since identifying the most vulnerable group is essential for targeted policy measures, efforts are made in this paper on disaggregating households by income level based on Malaysia's household income and expenditure surveys in 2009/2010. The disaggregation allows comparing different impacts of fuel subsidy reform on different income groups and also assessing the effectiveness and economic feasibility of compensation policies targeting disadvantaged groups, which are not seen in existing literature. Increased commodity prices due to higher energy prices after subsidy removal were expected to hurt the poor more than high income groups (IISD, 2013).

Indirect natural gas subsidies provided by PETRONAS have different funding from petroleum subsidies. And more than half of Malaysia's electricity is generated by natural gas. Given the magnitude of gas subsidies, it is worthwhile to investigate its transmission mechanisms of gas subsidies individually. Therefore, unlike existing studies that focus on petroleum subsidies or analyze government subsides/energy subsidies as a whole, analysis of gas subsidies is within the scope of this paper. The saved budget from subsidy removal in the existing studies is not planned for any other use other than cutting budget deficit. This assumption is also considered as the default setting in this paper, but spending the saved budget or increased government revenue on infrastructure development or/and education, health and other public services is additionally evaluated as alternative options for the government to better utilize the extra funding. Last, the latest 2010 I-O tables used in this paper is supposed to be more appropriate in accessing the subsidy 
reform initiative than the 2005 version of I-O tables used in previous studies. This is because during the Mahathir's premiership up to 2003, subsidy was mainly in the form of forgone tax revenuelittle in direct subsidy (Thillainathan 2009; Hamid and Rashid 2012). The amount of fuel subsidies was kept at unsustainable level in more recent years.

\section{Methodology and Data}

In this paper, a static Malaysian CGE model is developed to quantify the potential impacts of energy subsidy reform. In the model, the behaviors of each agent, such as households, firms and the government, are specified by a system of non-linear functions. When an external shock comes, the interactions of these agents would lead the economy to a new equilibrium. Comparing equilibriums obtained under different scenarios can provide policy makers insights into long-run economic planning and policy-making. Therefore, CGE model has been widely used in analysis of government regulation, tax reform, trade liberation, regional cooperation and environmental issues (e.g., Hudson and Jorgenson, 1974; Ballard et al., 1985; Martin et al., 1992; Harrison and Rutherford, 1999; Dixon, 2006; Hosoe, 2006; Perali et al., 2012; Parrado and De Cian, 2014).

To be consistent with the classification of I-O tables and household income and expenditure survey, the Malaysian economy in this study is divided into 15 non-energy sectors ${ }^{3}$, i.e. Agriculture, Food \& Wear, Wood \& Paper, Chemicals \& Metal, Machinery, Vehicles, Construction, Wholesale \& Retail trade, Hotel \& Restaurant, Transport, Communications \& Amusement, Housing, Education, Health, Other services, and 5 energy sectors, i.e. Electricity, Crude Oil, Natural Gas, Other Mining, Petroleum. ${ }^{4}$ The Natural Gas sector in this study is an aggregate of natural gas and gas sectors in the

\footnotetext{
${ }^{3}$ For ease of calculation, the data treatment scheme-1 is used to match the I-O classification and energy classification (Su et al., 2010).

${ }^{4}$ In Malaysia's I-O tables, coal is not separately listed but included in the Other Mining sector. More than one third of electricity in Malaysia is generated from coal.
} 
I-O tables. Each sector is assumed to have one representative producer. The economy has four representative households, which represents the lowest 15\% (H1), lower-middle $40 \%$ (H2), uppermiddle $30 \%(\mathrm{H} 3)$ and highest $15 \%(\mathrm{H} 4)$ households by income. ${ }^{5}$

\subsection{The model}

Figure 1 describes the nested production structure for all sectors, which consists of three broad categories of inputs: factor inputs (i.e. labor and capital), energy inputs and non-energy intermediate inputs (see Eqs. A1-A6 in the Appendix A). Domestic input and imported input of the same variety are treated as imperfect substitute in production, and aggregated using a constant elasticity of substitution (CES) function. The fossil fuel bundle, energy bundle, capital-labor bundle and capitallabor-energy bundle are all CES aggregations. Following a Leontief function, the capital-laborenergy input and non-energy intermediate inputs are then aggregated into the gross output, which is either supplied to domestic market or exported. At each level of the production structure, the producer is assumed to choose a bundle of inputs that maximizes profit (i.e. revenue minus costs for factor inputs/energy inputs/non-energy intermediate inputs and taxes, etc.) subject to its production technology. Subsidies to petroleum, gas and other commodities enter profit functions as negative costs or effective revenues, and will affect the effective prices of composites at corresponding production levels. The influence of subsidies will be transmitted up to the gross output along the production structure. For crude oil, natural gas, other mining and petroleum, domestic supply and exports are not differentiated. For the remaining sectors, the gross output is further transformed into domestic commodity and export commodity using a constant elasticity of transformation function. Similar to production, the firm also maximizes profit subjection to transformation function.

\footnotetext{
${ }^{5}$ The household survey data is used to differentiate the households into four income groups. Similar technique is used in Su et al. (2017) on Singapore's household income group disaggregation.
} 
The representative households receive factor income by supplying capital and labor inputs, and receive transfer payments from the government and the rest of the world (ROW). After paying income taxes and making non-tax payments to the government, the households consume commodities and save. As the Malaysian government has a budget deficit, part of the household savings is lent to the government to close its budget deficit. The lending could be interpreted as equivalent to purchasing government bond. The total consumption of each representative household is subject to its budget constraint. The consumption of each commodity $j$ and the respective shares of domestic commodity $j$ and imported commodity $j$ are determined following a nested CES structure (see Eqs. A7-A8 in the Appendix A).

Government revenue is mainly from tax collection. According to the data, taxes in the model include (1) labor income tax, (2) capital income tax, (3) production tax on gross output, (4) sale tax on final consumption and investment, and (5) sale tax on exports. Tax revenue and non-tax payments as well as with borrowings from the households allow the government to spend on goods and services such as education, health and national defence, save for development investment, provide subsidies, and also make transfer payments to the households and the ROW. In this study, government subsidies are provided for products of the Agriculture, Food \& Wear, Chemical \& Metal and Petroleum sectors. The total government consumption is a composition of commodities, each of which is a CES combination of domestic and imported products, following a Cobb-Douglas function (see Eqs. A9-A10 in the Appendix A). That is, the government is assumed to consume each variety of commodity in a fixed proportion of the total government consumption.

Domestic savings by government and households as well as foreign savings arising from trade balance are assumed to be entirely used on investment. Similar to the government consumption, the total investment is also based on a Cobb-Douglas function and the substitution between domestic and imported products follows a CES function (see Eqs. A11-A12 in the Appendix A). In addition to 
market-clear conditions for commodities, labor and capital, several other assumptions are made to close the model: (a) household saving rates are exogenous, (b) government saving rate is exogenous or government savings are exogenous depending on scenarios, (c) prices of exports and imports are exogenous, and (d) foreign savings are fixed while the exchange rate is floating.

\subsection{Data}

The SAM is constructed according to the framework presented in Section 3.1. Economic data used are mainly from Malaysia's I-O Table 2010 (DOS, 2014) and Malaysia's Statistics Handbook (DOS, 2011b). According to the data, GDP and total exports of Malaysia in the base year 2010 were around RM 825.4 billion and 643.6 billion, respectively. The Malaysian government had RM 121.5 billion of tax revenue and RM 50.1 billion of non-tax revenue, and spent RM 106.5 billion on commodities (mainly education, health, public administration, defence and public order, and other public services), RM 52.8 billion on infrastructure development (i.e. government savings), RM 32.6 billion on transfer payments and RM 12.4 billion on commodity subsidies. As a result, the government had a budget deficit of approximately RM 32.6 billion in 2010. Most parameter values used in the simulation such as tax rates and saving rates are calibrated on a basis of the SAM, but elasticities of substitution/transformation in production, consumption and investment functions are set in line with those used in the MIT EPPA model (e.g. Paltsev et al., 2005), the GTAP model (e.g. Huff et al., 1997) and Solaymani and Kari (2014).

The household disaggregation is based on information from the Malaysia Household Income and Basic Amenities Survey Report 2009 and Malaysia Report on Household Expenditure Survey 2009 (DOS, 2011a and 2012). The figures show that income inequality is quite serious in Malaysiathe bottom $15 \%$ of households $(\mathrm{H} 1)$ receive around $4 \%$ of total income while the top $15 \%$ of households (H4) receive more than $40 \%$ of total income. Energy related data such as energy supply, 
sectoral consumption of fossil fuels, retail fuel prices in Malaysia, etc., are obtained from the Malaysia National Energy Balance and Malaysia Energy Statistics Handbook (EC, 2012 and 2015). These data are utilized to disaggregate crude oil \& natural gas sector and electricity \& gas sector in the I-O tables and calculate $\mathrm{CO}_{2}$ emissions from fossil fuel combustion. Using emissions factors suggested in IPCC (2006), Malaysia's total carbon emissions are found to be around 188.5 million ton in $2010 .^{6}$

\section{Simulation and Results}

Three broad categories of scenarios are designed for the assessment, which are (1) no petroleum subsidies, (2) no gas subsidy and (3) no petroleum and gas subsidies. For gas subsidy, removal in power sector only and complete removal (i.e. in power, industries and commercial sectors) are simulated separately as sub-scenarios. As cutting budget deficit is the primary incentive for the government to abandon subsidy policy, fiscal expenditure is by default set to be fixed at the level in 2010. But another extreme situation, to relocate the saved budget or increased government revenue on consumption of education, health and other public services, etc. and infrastructure development as in 2010 (i.e. floating setting), is also considered as an alternative. While the sustainability of fiscal system discourages the floating expenditure setting, providing better infrastructure and more public services can explicitly show the public that the government is utilizing the freed budget or increased revenue in a more beneficial way. ${ }^{7}$

In this study, direct government transfer is chosen as the compensation option for the most

\footnotetext{
${ }^{6}$ Emissions from gas flaring reinjection \& use (specified in the National Energy Balance table) is not considered here.

${ }^{7}$ In-between options could be using the money entirely on (i) consumption of commodities, or (ii) savings for infrastructure development, respectively. Simulated macro impacts are close to those under the floating setting in scenario (i), and almost the same to those under the fixed setting in scenario (ii). Considering the length of the paper, the simulated results are not included but available upon request.
} 


\subsection{Impacts of subsidy removal with fixed fiscal expenditure}

Table 3 displays the simulated macro impacts of petroleum and gas subsidy removal, with fiscal expenditure fixed and no compensation provided to the most disadvantaged groups. Theoretically, removing fuel subsidies would induce more efficient distribution of resources among different sectors and improve economic efficiency. But higher price also means higher production cost and a subsequent increase in overall price level. This is one of the potential reasons for diverse evaluation results obtained in the literature.

In the case of Malaysia, GDP would increase by $0.07 \%$ (or RM 0.60 billion) when petroleum subsidies are completely removed. Total exports increase by $1.01 \%$ (or RM 6.5 billion), which is dominated by the Machinery and Petroleum. According to the I-O data, the Machinery sector accounts for more than one third of Malaysia's total exports, and is not petroleum intensive. As a result, the sector benefits from resource relocation from more intensive sectors and expands. And

\footnotetext{
${ }^{8}$ Labor income tax rebate to $\mathrm{H} 1$ have almost identical impacts as direct government transfer payment. The simulation results are not reported due to space limit, but are available upon request.
} 
higher price lowers the country's consumption of petroleum, so that more petroleum products are available for exports. The petroleum sector contributes to $7 \%$ of Malaysia's total exports. As expected, budget deficit declines significantly by $28.2 \%$ (or RM 9.2 billion), and total carbon emissions reduce by $1.84 \%$ (or 3.5 million ton $\mathrm{CO}_{2}$ ). For households, lower-income groups tend to be slightly less affected than higher-income groups, which is mainly because petroleum products account for a larger proportion in the consumption baskets of higher income groups. Intuitively, automobiles and even motorbikes are not affordable to the poor, so the price shock to diesel and gasoline has smaller direct impacts on them.

Economic gain tends to be much larger when the subsidy reform is on gas, but the impact on exports and households are different from the petroleum case. GDP is simulated to increase by $0.28 \%$ (or RM 2.3 billion) when natural gas sold to power generators are no longer subsidized and $0.53 \%$ (or RM 4.4 billion) when gas subsidy is completely removed in power, industries and commercial sectors. However, exports would decline in these two sub-scenarios. And again, the trend is mainly driven by the sinking exports of machinery and petroleum products. The Machinery sector is electricity intensive and thus suffers from higher electricity price as a result of unsubsidized power generation form natural gas. Producers and households would more or less switch from more expensive natural gas and electricity towards domestic petroleum, since substitution exists across different fuels as well as between fossil fuel and electricity. Therefore, the amount of petroleum products available for exports reduces. The saved gas subsidy does not directly go to the government, but becomes the producer's operating surplus or capital income. Budget deficit reduction here mainly arises from higher tax revenue, and is thus much smaller than in the case of removing petroleum subsidies.

Quite the contrary, carbon emissions reduction is more than doubled than in Scenario 1a. The results are consistent with Malaysia's power generation mix- more than $50 \%$ of electricity is 
generated by natural gas while less than $5 \%$ by petroleum products. Relatively, the emission reduction is smaller in the complete removal scenario as more energy is needed for the higher economic/GDP growth. For households, the lower-income groups are moderately or negligibly affected by the gas subsidy removal, and higher-income households are even better off in both subscenarios. The explanation is that: first, natural gas used by households are not initially subsidized so that all the households are only indirectly affected by the increase in the price of electricity and other commodities; second, every income group can benefit from the economic growth to some degree; third, the previously forgone revenue turns into capital income, which is then distributed to households following the patterns in the household income survey. Obviously, the higher-income groups would receive much higher proportions of the redistributed benefits than the lower-income groups.

When the reform proceeds to both petroleum and gas subsidies, the macro impacts are close to, but not equal to, the accumulated impacts of individual cases. The figures show that GDP would grow more than the sum in separate reforms. When all the fuel subsidies are removed, GDP could increase by $0.65 \%$ (or RM 5.4 billion), which is a significant change in any country. While removing the two types of fuels subsidies has opposite impacts on exports, the net impacts of removing both turn to be positive. The thorough reform in Scenario 3a could also reduce around 1/3 of the budget deficit (or RM 11.4 billion) and 6\% of total carbon emissions (or 11.1 million ton $\mathrm{CO}_{2}$ ), which in principle achieves the primary target of the government and meanwhile implies that fuel subsidy reform could be an important policy instrument for Malaysia to mitigate climate change and achieve its INDC target. As the impacts of removing petroleum subsidies dominate, all household groups would be affected by the complete reform. But the net impacts tend to be slightly better than the sum in separate reforms. 
Table 4 shows how sectoral outputs are affected by fuel subsidy reforms. The general observation is that petroleum intensive sectors are more affected by petroleum subsidy removal and electricity intensive sectors are more affected by gas subsidy removal. For example, the agriculture sector and transport sector are petroleum intensive, so their outputs decrease due to higher production costs when petroleum subsidies are removed but increase due to relocation of labor and capital from more affected sectors when gas subsidy is removed. On the other hand, the machinery sector is electricity intensive, so its output increases in petroleum subsidy removal scenario but decreases in gas subsidy removal scenario.

\subsection{Impacts of subsidy removal with floating fiscal expenditure}

Table 5 displays the macro impacts of fuel subsidy removals for the floating fiscal expenditure setting. The saved budget is set to be invested in infrastructure and spent on education, health and other public services as in the base year. Again, no compensation is provided to the lowest income households yet.

When only petroleum subsidies are removed, the increase in GDP by $0.04 \%$ (or RM 0.31 billion) tends to be smaller than in the fixed fiscal expenditure setting. As education, health and other public services are primarily produced and consumed domestically, the increased government expenditure on them stimulates relocation of resources to these sectors. Correspondingly, other sectors have to shrink and their exports would decrease. Also because of the re-spending of the saved subsidy, budget deficit would slightly decrease by $0.53 \%$ (or RM 0.17 billion) and government consumption would shoot up by $8.19 \%$ (or RM 8.7 billion). The service-dominated and thus less energy intensive government consumption consequently leads to greater carbon emissions reduction by $2.09 \%$ (or 3.9 million ton $\mathrm{CO}_{2}$ ) under the floating fiscal expenditure. 
All four household groups are worse off due to rising price level after the petroleum subsidy removal. The pattern that lower-income groups are relatively less affected remains. Interestingly, even if compared to the impacts in the fixed fiscal expenditure setting, the lower-income groups are less affected as well. The potential reasons could be: first, the shares of income received by lower income groups are relatively higher in the education, health and other services sectors than the average. So lower income groups could benefit from growth in these sectors stemming from more government consumption. Second, the extra government expenditure would increase supply of education, health and other services (mainly public administration) or/and enlarge government coverages of tuition fee and healthcare cost, etc. Regardless the exact policy tools, all income groups would be able to consume more these services at lower prices.

For gas subsidy removal, there is almost no difference in GDP growth between the fixed and floating fiscal expenditure scenarios. But exports would drop more in the floating setting due to the increased government expenditure on domestic services. As gas subsidies are provided by PETRONAS, removing gas subsidies can only indirectly affect the fiscal budget through higher tax revenue. According to fiscal expenditure style in 2010, the government spends more than its income. Therefore, budget deficit and government consumption both end up with an increase in the two subscenarios. The impacts on carbon emissions reduction and different income groups are quite similar to those in the fixed fiscal expenditure sub-scenarios. Particularly, when gas subsidies are removed in all sectors, even the lowest-income group would be slightly better off than the baseline.

As in Scenario 3a, the macro impacts are close to the accumulated impacts of individual cases when all fuel subsidies are removed. Budget deficit would almost remain unchanged after the impacts of removing petroleum and gas subsidies offset with each other. As in separate removal scenarios, carbon emissions reduction is more significant than under the setting of fixed fiscal expenditure. 
Table 6 shows the response of each sector to the fuel subsidy reforms. The major differences between the results in Table 4 and Table 6 lie in the Education, Health and Other Services sectors. The three sectors are overall moderately affected in the fixed fiscal expenditure scenarios, but significantly expand with the increased government expenditure on them. The expansion also causes resource re-allocation within the economy and makes other sectors also more or less perform differently than in Table 4. The impacts on some sectors, such as Vehicles, Construction and Housing, would even reverse in some sub-scenarios.

\subsection{Impacts of compensation policy}

In addition to household consumption in volume, compensating variation (CV) and equivalent variation (EV) are also considered in this study to discuss the loss of welfare arising from energy subsidy removal. Intuitively, CV refers to the amount of money a household must be compensated for the price changes, and EV refers to the amount of money a household would accept in lieu of the price changes (see Eqs. A13-A14 in the Appendix A). Negative sign implies that the price changes would make the household worse off.

Table 7 lists the simulated $\mathrm{CV}$ and $\mathrm{EV}$ values for each income group, the signs of which are consistent with household consumption in volume. ${ }^{9}$ The figures imply that, compared to the huge amount of fuel subsidies provided directly or indirectly, the government does not need to pay much to compensate households' loss of welfare stemming from the subsidy reforms. For example, to make the bottom $15 \%$ of households no worse off than baseline, less than RM 0.3 billion is required. Even if the compensation extends to the lower-middle $40 \%$ of households, the total transfer payment needed is less than $15 \%$ of petroleum subsidies paid in 2010 .

\footnotetext{
${ }^{9}$ The figures are displayed in Billion RM so as to have a direct comparison with subsidies in size.
} 
Both direct government transfer and labor income tax rebate are considered as potential compensation policy instruments. Although different in transmission mechanism, the simulation results show that the two compensation instruments are almost indifferent in terms of economic impacts. To save space, only the impact of direct government transfer are reported here. No compensation is needed in Scenario $2 b \_P I C$ as all income groups are better off after the reform. In this study, the compensation is provided to the point that the bottom $15 \%$ households $(\mathrm{H} 1)$ are no worse than the baseline status. Figures in Table 8 show that compensating the lowest income group would have almost no additional impacts on GDP, exports, carbon emissions reduction and the other three uncompensated income groups. Only budget deficit and government consumption would display slightly larger differences from their counterparts in Table 4 and Table 6.

\section{Discussions and Conclusion}

In ASEAN, subsidies not only discourage development of clean energy, fossil fuel exploration and infrastructure investment, prevent integration of energy markets as required by the ASEAN Economic Community, but also limit the possibility to optimize the trade of low-carbon resources. Reform of fossil fuel subsidies, together with promotion of renewables and energy efficiency, regional market integration and connectivity, are key instruments to achieving a cleaner, and more sustainable energy mix for ASEAN (Shi, 2016). Low oil prices in recent few years provide an appropriate timing of fuel subsidy removal, the delay of which will primarily increase costs for the government and leave little room for policy space when energy prices are higher than expected (Wu et al., 2012).

This study quantitatively investigates the impacts of removing fuel subsidies on Malaysia's economic performance, household welfare and carbon emissions. A dedicated Malaysia CGE model was built, with breakdown of households by income incorporated to allow estimating the 
differentiated impacts on households. The simulation results demonstrate that removing fuel subsidies could improve economic efficiency and relocate resources to less energy intensive sectors, producing both economic and environment benefits. In the interest of economic gain, all fuel subsidies should be removed to maximize the GDP growth. But from the perspective of climate change mitigation, retaining gas subsidy in industries and commercial sectors is favored, because slightly higher reduction in carbon emissions could be achieved. However, the small amount of additional emissions reduction would be at the expense of nearly halved GDP growth, which seems not worth.

Households at all income levels would be worse off in most scenarios as the impacts of rising price level dominate. In petroleum subsidy scenarios, lower income groups tend to suffer less than their high income peers because petroleum products account for smaller portions in their consumption baskets. In gas subsidy removal scenarios, the two high income groups (H3 and H4) are always better off than baseline. This is because gas subsidy removal turns the gas supplier's forgone revenue into operating surplus or capital income, which is then distributed disproportionally to different income groups. The small shares received by the two low income groups $(\mathrm{H} 1$ and $\mathrm{H} 2)$ can hardly or narrowly help offset the impacts of higher price level. From the public policy perspective, protection of disadvantaged groups is one of the key tasks for the government. The simulated results demonstrate that compensation policy through direct transfer payment could make the poorest income group no worse than baseline while have almost no extra impacts on GDP growth and emissions reduction.

A comparison of the simulation results between fixed fiscal expenditure and floating expenditure shows that the two setting have their respective advantages. The former setting is featured with significant reductions in budget deficit, which is the primary intention of the reform. The latter setting tends to slightly compromise GDP growth but perform better in emission 
reduction. More importantly, all income groups except for the top $15 \%$ households will be less affected in the floating expenditure scenarios because of the increased supplies of education, health and other public services by the government. At sectoral level, changes in outputs differ across sectors and display no common preference over any specific scenario. Generally, petroleum intensive sectors are more affected by petroleum subsidy removal, while electricity intensive sectors are more affected by gas subsidy removal.

The first policy impaction based on the simulation results is that fuel subsidies should be phased out completely. However, although the simulation results support complete removal, the politically sensitivity demands holistic approach, strategic planning and actions (Shi, 2016). While preparation of subsides removal will take time, there is no excuse to delay initial actions, such as public education and information campaign (Shi, 2016). Communications to the public and industries are particularly important, especially in an energy-producing country where the citizens take low energy prices for granted (OECD, 2013). Traditional media, official websites, roadshows and public workshops, etc., are all useful platforms to communicate why the reform must be carried out, in what ways the saved subsidy cost would be utilized and how the vulnerable groups would be protected, as well the public's feedback and concerns. The effectiveness of the communications depends on the public's trust in the government, which is in turn firmly related to the transparency and credibility of the government.

The second policy implication is on the use of the saved or increased budget. For the benefit of immediate fiscal deficit reduction and economic growth, the fiscal expenditure should be fixed. However, increasing expenditure on education, health and other services sectors could alleviate the welfare loss of most households due to more services available to them at lower prices, which makes it easier to gain their supports for the reform. Furthermore, more schools and hospitals, less time on the waitlist and in the queue, better facilities and equipment, etc., can all be visually 


\section{Acknowledgements}

Work on this paper benefited from the financial support of the Economic Research Institute for ASEAN and East Asia (ERIA) from its project on "Institutional Strategy and Economic Impacts by Energy Subsidy Removals in EAS region”. The authors are grateful to Shigeru Kimura, Phoumin Han, Tsani Fauziah and participants in the two project working group meetings for helpful comments and suggestions. All errors are authors' own responsibilities. 


\section{Appendix A. Key Model Specifications}

\section{Production Activity}

The gross output of sector $\mathrm{j}\left(Y_{j}\right)$ is produced following a multi-level nested production structure. At each level of the production structure, the firm maximizes profits (i.e. revenue minus costs for factor inputs, intermediate inputs and taxes, etc.) subject to production technology.

Capital $\left(K_{j}\right)$ and labor $\left(L_{j}\right)$ are combined first into a capital-labor input $\left(K L_{j}\right)$ following a constant elasticity of substitution (CES) function:

$K L_{j}=a_{K L, j}\left(\lambda_{K, j} K_{j}^{\rho_{K L, j}}+\lambda_{L, j} L_{j}^{\rho_{K L, j}}\right)^{\frac{1}{\rho_{K L, j}}}$

where $a_{K L, j}$ is the scaling coefficient of $K L_{j}$ input production, $\lambda_{K, j}$ and $\lambda_{L, j}$ are respectively the input share coefficients of capital and labor that sum up to 1 , and $\sigma_{K L, j}=\frac{1}{1-\rho_{K L, j}}$ is the elasticity of substitution between capital and labor.

In Malaysia, there are mainly four types of fossil fuel input: crude oil, gas, petroleum and other mining (coal included). All of them are CES aggregates of domestically processed and directly imported products, and are further composited into the aggregate fossil fuel input $\left(F F_{j}\right)$ using a CES function:

$F F_{j}=a_{F F, j}\left(\sum \lambda_{F, j} F_{i, j}^{\rho_{F F, j}}\right)^{\frac{1}{\rho_{F F, j}}}$

where $a_{F, j}$ is the scaling coefficient of $F F_{j}$ input production, $\lambda_{F, j}$ is the input share coefficient of the $i$-th fossil fuel input $\left(F_{i, j}\right)$ that sum up to 1 ( $i=$ crude oil, gas, petroleum and other mining), and $\sigma_{F F, j}=\frac{1}{1-\rho_{F F, j}}$ is the elasticity of substitution among the fossil fuel inputs.

The total energy input $\left(E_{j}\right)$ is a CES composite of the aggregate fossil fuel input and electricity $\left(E L C_{j}\right):$

$E_{j}=a_{E, j}\left(\lambda_{F F, j} F F_{j}^{\rho_{E, j}}+\lambda_{E L C, j} E L C_{j}^{\rho_{E, j}}\right)^{\frac{1}{\rho_{E, j}}}$

where $a_{E, j}$ is the scaling coefficient of $E_{j}$ input production, $\lambda_{F F, j}$ and $\lambda_{E L C, j}$ are the input share 
coefficients that sum up to 1 , and $\sigma_{E, j}=\frac{1}{1-\rho_{E, j}}$ is the elasticity of substitution between the fossil fuel input and electricity.

Then the capital-labor input and energy input are combined into the capital-labor-energy input $\left(K L E_{j}\right)$ following a CES function:

$K L E_{j}=a_{K L E, j}\left(\lambda_{K L, j} K L_{j}^{\rho_{K L E, j}}+\lambda_{E, j} E_{j}^{\rho_{K L E, j}}\right)^{\frac{1}{\rho_{K L E, j}}}$

where $a_{K L E, j}$ is the scaling coefficient of $K L E_{j}$ input production, $\lambda_{K L, j}$ and $\lambda_{E, j}$ are the input share coefficients that sum up to 1 , and $\sigma_{K L E, j}=\frac{1}{1-\rho_{K L E, j}}$ is the elasticity of substitution between the capital-labor input and energy input.

Finally, $h$ non-energy intermediate inputs $\left(I N_{j}\right)$ and the capital-labor-energy input are aggregated into gross output following a Leontief function:

$$
Y_{j}=\min \left(\frac{I N_{1, j}}{\phi_{1, j}}, \frac{I N_{2, j}}{\phi_{2, j}}, \ldots, \frac{I N_{h, j}}{\phi_{h, j}}, \frac{K L E_{j}}{\phi_{K L E, j}}\right)
$$

where $\phi_{h, j}$ and $\phi_{K L E, j}$ are the input requirement coefficients of the $h$-th non-energy intermediate input and the capital-labor-energy input for a unit output of $Y_{j}$, respectively. Each non-energy intermediate input is a CES composite of domestic and imported commodities of the same variety.

For some of the sectors, the gross output is further transformed into domestic commodities $\left(D_{j}\right)$ and export commodities $\left(X_{j}\right)$ using a constant elasticity of transformation (CET) function: $Y_{j}=a_{Y, j}\left(\beta_{D, j} D_{j}^{\rho_{Y, j}}+\beta_{X, j} X_{j}^{\rho_{Y, j}}\right)^{\frac{1}{\rho_{Y, j}}}$

where $a_{Y, j}$ is the scaling coefficient of the transformation, $\beta_{D, j}$ and $\beta_{X, j}$ are respectively the output share coefficients of the domestic and export commodities that sum up to 1 , and $\sigma_{Y, j}=\frac{1}{\rho_{Y, j}-1}$ is the elasticity of transformation for gross output $j$.

\section{Household}

Household income are mainly from payments for factor inputs and transfer payment from the government. The disposable income (i.e. net of income tax) is then used on consumption of 
commodities, savings, non-tax payments to the government and transfer payment to the rest of the world. The representative household is assumed to maximize its utility from total consumption $(C)$ subject to budget constraint.

For each variety of commodity except for electricity, the household have both domestic and imported choices. So the consumption of each commodity $\left(C_{i}\right)$ is a CES composite of consumption of domestic commodity $\left(D C_{i}\right)$ and consumption of imported commodity $\left(M C_{i}\right)$ :

$$
C_{i}=\left(\omega_{D C, i}^{\frac{1}{\gamma_{C, i}}} D C_{i}^{\frac{\gamma_{C, i}-1}{\gamma_{C, i}}}+\omega_{M C, i}^{\frac{1}{\gamma_{C, i}}} M C_{i}^{\frac{\gamma_{C, i}-1}{\gamma_{C, i}}}\right)^{\frac{\gamma_{C, i}}{\gamma_{C, i}-1}}
$$

where $\omega_{D C, i}$ and $\omega_{M C, i}$ are respectively the consumption share coefficients that sum up to 1 , and $\gamma_{C, i}$ is the elasticity of substitution between domestic and imported commodities of variety $i$.

The total consumption aggregates consumption of individual commodities following a CES function:

$$
C=\left(\sum \omega_{H, i}^{\frac{1}{\gamma_{H, i}}} C_{i}^{\frac{\gamma_{H, i}-1}{\gamma_{H, i}}}\right)^{\frac{\gamma_{H, i}}{\gamma_{H, i}-1}}
$$

where $\omega_{H, i}$ is the consumption share of composite commodity $i$ that sum up to 1 , and $\gamma_{H, i}$ is the elasticity of substitution among commodities.

\section{Government}

Government collects tax and non-tax revenues, which are partly saved for development/infrastructure investment and partly spent on consumption of commodities. So total government consumption $(G)$ is assumed to be a composition of consumption of commodities $\left(G_{i}\right)$ based on a Cobb-Douglas function:

$$
G=\prod G_{i}^{\mu_{G, i}}
$$

where $\mu_{G, i}$ is the consumption share of each commodity in total government consumption and $G_{i}$ is a CES aggregate of domestic commodity $\left(D G_{i}\right)$ and imported commodity $\left(M G_{i}\right)$ :

$G_{i}=\left(\omega_{D G, i}^{\frac{1}{\gamma_{G, i}}} D G_{i}^{\frac{\gamma_{G, i}-1}{\gamma_{G, i}}}+\omega_{M G, i}^{\frac{1}{\gamma_{G, i}}} M G_{i}^{\frac{\gamma_{G, i}-1}{\gamma_{G, i}}}\right)^{\frac{\gamma_{G, i}}{\gamma_{G, i}-1}}$

where $\omega_{D G, i}$ and $\omega_{M G, i}$ are the consumption share coefficients that sum up to 1 , and $\gamma_{G, i}$ is the elasticity of substitution between domestic and imported commodities of variety $i$. 


\section{Investment}

Household savings, government savings and foreign savings are assumed to be entirely used for investment. Similar to government consumption, total investment $(V)$ is a Cobb-Douglas composite of investment on individual commodities $\left(V_{i}\right)$ :

$$
V=\prod V_{i}^{\mu_{V, i}}
$$

where $\mu_{V, i}$ is the consumption share of each commodity in total investment, and investment on each individual commodity is a CES composite of domestic commodity $\left(D V_{i}\right)$ and imported commodity $\left(M V_{i}\right)$ :

$V_{i}=\left(\omega_{D V, i}^{\frac{1}{\gamma_{V, i}}} D V_{i}^{\frac{\gamma_{V, i}-1}{\gamma_{V, i}}}+\omega_{M V, i}^{\frac{1}{\gamma_{V, i}}} M V_{i}^{\frac{\gamma_{v, i}-1}{\gamma_{V, i}}}\right)^{\frac{\gamma_{V, i}}{\gamma_{V, i}-1}}$

where $\omega_{D V, i}$ and $\omega_{M V, i}$ are the investment share coefficients that sum up to 1 , and $\gamma_{V, i}$ is the elasticity of substitution between domestic and imported commodities of variety $i$.

\section{Compensating variation (CV) and equivalent variation (EV)}

In addition to household consumption in volume, compensating variation (CV) and equivalent variation (EV) are also considered in this study to discuss the loss of welfare arising from energy subsidy removal. $\mathrm{CV}_{s}$ refers to the amount of money the $s$-th household must be compensated for the price changes, while $\mathrm{EV}_{s}$ refers to the amount of money the $s$-th household would accept in lieu of the price changes. They can be calculated following the functions:

$$
\begin{aligned}
& C V_{s}=\frac{D I_{s}^{1}}{p_{s}^{1} / p_{s}^{0}}-D I_{s}^{0} \\
& E V_{s}=D I_{s}^{1}-\frac{p_{s}^{1}}{p_{s}^{0}} D I_{s}^{0}
\end{aligned}
$$

whand $D I_{s}^{0}$ and $D I_{s}^{1}$ are respectively the disposable income of the $s$-th household before and after the price changes, and $p_{s}^{0}$ and $p_{s}^{1}$ are respectively the consumer price indexes of the $s$-th household before and after the price changes. Negative sign implies that the price changes would make the household worse off. 


\section{References}

Acar, S., Yeldan, A.E., 2016. Environmental Impacts of Coal Subsidies in Turkey: A General Equilibrium Analysis. Energy Policy 90, 1-15.

Adam, S., Pakiam, R., 2014. Malaysia Scraps Fuel Subsidies as Najib Ends Decades-Old Policy. Bloomberg.

Anderson, K., McKibbin, W.J., 2000. Reducing Coal Subsidies and Trade Barriers: Their Contribution to Greenhouse Gas Abatement. Environment and Development Economics 5, 457481.

Bacon, R., Kojima, M., 2006. Coping with Higher Oil Prices. World Bank, Washington, D.C.

Ballard, C.L., Fullerton, D., Shoven, J.B., John, W., 1985. A General Equilibrium Model for Tax Policy Evaluation. University of Chicago Press for the National Bureau of Economic Research, Chicago.

Burniaux, J.-M., Chateau, J., Sauvage, J., 2011. The Trade Effects of Phasing Out Fossil-Fuel Consumption Subsidies. OECD Trade and Environment Working Papers, 2011/05.

Burniaux, J.-M., Martin, J.P., Oliveira-Martins, J., 1992. The Effect of Existing Distortions in Energy Markets on the Costs of Policies to Reduce $\mathrm{CO}_{2}$ Emissions: Evidence from GREEN. OECD Economic Studies 19, 141-165.

Burniaux, J.M., Chateau, J., 2011. Mitigation Potential of removing Fossil Fuel Subsidies: A General Equilibrium Assessment. Economics Department Working Papers, NO. 853.

Clements, B., Coady, D., Fabrizio, S., Gupta, S., Alleyne, T., Sdralevich, C., 2013. Energy Subsidy Reform: Lessons and Implications. International Monetary Fund, Washington, D.C.

Dennis, A., 2016. Household Welfare Implications of Fossil Fuel Subsidy Reforms in Developing Countries. Energy Policy 96, 597-606.

Dixon, P.B., 2006. Evidence-based Trade Policy Decision Making in Australia and the Development of Computable General Equilibrium Modelling. Centre of Policy Studies and IMPACT Centre Working Papers, G-163.

DOS, 2011a. Report on Household Expenditure Survey, Malaysia 2009/10. Department of Statistics, Malaysia.

DOS, 2011b. Statistics Handbook of Malaysia, 2011. Department of Statistic, Malaysia.

DOS, 2012. Malaysia Household Income and Basic Amenities Survey Report, 2009. Department of Statistics, Malaysia.

DOS, 2014. Malaysia Input-Output Tables, 2010. Department of Statistics, Malaysia.

EC, 2012. National Energy Balance 2010. Energy Commission, Malaysia.

EC, 2015. Malaysia Energy Statistics Handbook 2015. Energy Commission, Malaysia.

Hamid, K.A., Rashid, Z.A., 2012. Economic Impacts of Subsidy Rationalization in Malaysia, in: Wu, Y., Shi, X., Kimura, F. (Ed.), Energy Market Integration in East Asia: Theories, Electricity Sector and Subsidies. Economic Research Institute for ASEAN and East Asia, Jakarta.

Harrison, G.W., Rutherford, T.F., 1999. Burden Sharing, Joint Implementation, and Carbon Coalitions, in: Carraro, C. (Ed.), International Environmental Agreements on Climate Change. Springer Netherlands, Dordrecht, 77-108.

Hosoe, N., 2006. The Deregulation of Japan's Electricity Industry. Japan and the World Economy 18, 
230-246.

Hudson, E.A., Jorgenson, D.W., 1974. U. S. Energy Policy and Economic Growth, 1975-2000. The Bell Journal of Economics and Management Science 5, 461-514.

Huff, K.M., Hanslow, K., Hertel, T.W., Tsigas, M.E., 1997. GTAP Behavioral Parameters, in: Hertel, T.W. (Ed.), Global Trade Analysis: Modeling and Applications. Cambridge University Press.

IEA, 1994. Energy Policies of IEA Countries, 1993 Review. OECD, Paris.

IEA, 1995. Energy Policies of IEA Countries, 1994 Review. OECD, Paris.

IEA, 1999. Looking at Energy Subsidies: Getting the Prices Right. World Energy Outlook 1999. International Energy Agency, Paris.

IEA, 2013. Southeast Asia Energy Outlook. World Energy Outlook Special Report. International Energy Agency, Paris.

IEA, UNEP, 2001. Energy Subsidy Reform and Sustainable Development: Challenges for Policymakers. International Energy Agency/United Nations Environment Programme, New York.

IISD, 2013. A Citizens' Guide to Energy Subsidies in Malaysia. International Institute for Sustainable Development, Manitoba.

IISD, 2014. Lessons Learned: Malaysia's 2013 Fuel Subsidy Reform. International Institute for Sustainable Development, Manitoba.

Ilias, S., Lankanathan, R., Poh, W., 2012. Low Inflation, but at a High Price, Malaysia CPI: Inflation and subsidy. Maybank IB Research, Malaysia.

IPCC, 2006. 2006 IPCC Guidelines for National Greenhouse Gas Inventories, Japan.

Koplow, D.N., 1993. Federal Energy Subsidies: Energy, Environmental and Fiscal Impacts. Alliance to Save Energy, Massachusetts.

Kosmo, M., 1989. Commercial Energy Subsidies in Developing Countries: Opportunity for Reform. Energy Policy 17, 244-253.

Larsen, B., 1994. World Fossil Fuel Subsidies and Global Carbon Emissions in a Model with Interfuel Substitution. World Bank, Washington, D.C.

Larsen, B., Shah, A., 1992. World Fossil Fuel Subsidies and Global Carbon Emissions. World Bank, Washington, D.C.

Larsen, B., Shah, A., 1995. Global Climate Change, Energy Subsidies and National Carbon Taxes, in: Bovenberg, L., Cnossen, S. (Eds.), Public Economics and the Environment in an Imperfect World. Springer Netherlands, Dordrecht, pp. 113-132.

Light, M.K., 1999. Coal Subsidies and Global Carbon Emissions. The Energy Journal 20, 117-148.

Liu, W., Li, H., 2011. Improving Energy Consumption Structure: A Comprehensive Assessment of Fossil Energy Subsidies Reform in China. Energy Policy 39, 4134-4143.

Martin, J.P., Burniaux, J.-M., Nicoletti, G., Oliveira-Martins, J., 1992. The Costs of International Agreements to Reduce $\mathrm{CO}_{2}$ Emissions: Evidence from GREEN. OECD Economic Studies 19, 93-121.

NEAC, 2009. New Economic Model for Malaysia, Part 1. National Economic Advisory Council, Putrajaya.

OECD, 1996. Subsidies and Environment: Exploring the Linkages. OECD, Paris 
OECD, 1997a. Reforming Coal and Electricity Subsidies. OECD, Paris.

OECD, 1997b. Reforming Energy and Transport Subsidies: Environmental and Economic Implications. OECD, Paris.

OECD, 1998. Improving the Environment through Reducing Subsidies. OECD, Paris.

OECD, 2000. Environmental Effects of Liberalising Fossil Fuels Trade: Results from the OECD GREEN Model. OECD, Paris.

OECD, 2013. Analysing Energy Subsidies in the Countries of Eastern Europe, Caucasus and Central Asia. OECD, Paris.

Paltsev, S., Reilly, J.M., Jacoby, H.D., Eckaus, R.S., McFarland, J., Sarofim, M., Asadoorian, M., Babiker, M., 2005. The MIT Emissions Prediction and Policy Analysis (EPPA) Model: Version 4. MIT Joint Program on the Science and Policy of Global Change.

Parrado, R., De Cian, E., 2014. Technology Spillovers Embodied in International Trade: Intertemporal, Regional and Sectoral Effects in a Global CGE Framework. Energy Economics 41, 76-89.

Perali, F., Pieroni, L., Standardi, G., 2012. World Tariff Liberalization in Agriculture: An Assessment Using a Global CGE Trade Model for EU15 Regions. Journal of Policy Modeling 34, 155-180.

Porter, G., 2002. Subsidies and the Environment: the State of Knowledge. OECD, Paris.

Rentschler, J., 2016. Incidence and Impact: The Regional Variation of Poverty Effects due to Fossil Fuel Subsidy Reform. Energy Policy 96, 491-503.

Shi, X., 2016. The Future of ASEAN Energy Mix: A SWOT Analysis. Renewable and Sustainable Energy Reviews 53, 672-680.

Shi, X., Kimura, F., 2014. The Status and Prospects of Energy Market Integration in East Asia, in: $\mathrm{Wu}$, Y., Kimura, F., Shi, X. (Eds.), Energy Market Integration in East Asia: Deepen Understanding and Move Forward. Routledge for the Economic Research Institute for ASEAN and East Asia, Oxon and New York, pp. 9-24.

Su, B., Ang, B.W., Li, Y.Z., 2017. Input-output and Structural Decomposition Analysis of Singapore's Carbon Emissions. Energy Policy 105, 484-492.

Su, B., Huang, H.C., Ang, B.W., Zhou, P., 2010. Input-output analysis of $\mathrm{CO}_{2}$ Emissions Embodied in Trade: The Effects of Sector Aggregation. Energy Economics 32, 166-175.

Solaymani, S., 2016. Impacts of Energy Subsidy Reform on Poverty and Income Inequality in Malaysia. Quality \& Quantity 50, 2707-2723.

Solaymani, S., Kardooni, R., Kari, F., Yusoff, S.B., 2015. Economic and Environmental Impacts of Energy Subsidy Reform and Oil Price Shock on the Malaysian Transport Sector. Travel Behaviour and Society 2, 65-77.

Solaymani, S., Kari, F., 2014. Impacts of Energy Subsidy Reform on the Malaysian Economy and Transportation Sector. Energy Policy 70, 115-125.

Solaymani, S., Kari, F., Hazly Zakaria, R., 2014. Evaluating the Role of Subsidy Reform in Addressing Poverty Levels in Malaysia: A CGE Poverty Framework. The Journal of Development Studies 50, 556-569.

Teoh, S., 2012. Subsidy Cuts Frozen, Says PEMANDU. The Malaysian Insider. 
Thillainathan, R., 2009. A Critical Review of Price Control and Subsidies. Ekonomika 1, 5-7.

UNDP, 2012. Fossil Fuel Fiscal Policies and Greenhouse Gas Emissions in Viet Nam. United Nations Development Programme, Ha Noi.

UNEP, 2004. Energy Subsidies: Lessons Learned in Assessing Their Impact and Designing Policy Reforms. United Nations, Geneva.

UNEP, 2008. Reforming Energy Subsidies: Opportunities to Contribute to the Climate Change Agenda. United Nations Environment Programme, Paris.

World Bank, 2010. Analysis of the Scope of Energy Subsidies and Suggestions for the G-20 Initiative. World Bank, Washington, D.C.

Wu, Y., Shi, X., Kimura, F. (Eds.), 2012. Energy Market Integration in East Asia: Theories, Electricity Sector and Subsidies. Economic Research Institute for ASEAN and East Asia, Jakarta. 
Figure 1. Nested production structure 
Table 1. Overview of Malaysia's fuel subsidy policies

\begin{tabular}{|c|c|c|}
\hline Subsidies & Policy summary & Results \\
\hline \multirow{6}{*}{ 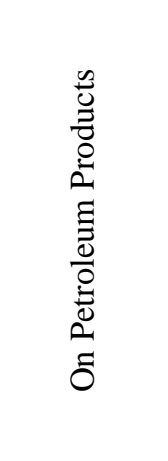 } & Provided by the government & \multirow{6}{*}{$\begin{array}{l}\text { Based on Malaysia's official statistics, the } \\
\text { budget for petroleum subsidies: } \\
\text { - only RM } 27 \text { million in } 1990 \\
\text { - rose to RM } 3.2 \text { billion in } 2000 \\
\text { - peaked at RM } 17.6 \text { billion in } 2008 \\
\text { - RM 9.6 billion in } 2010 \\
\text { (Hamid and Rashid, 2012) }\end{array}$} \\
\hline & Officially, an Automatic Pricing Mechanism & \\
\hline & (APM) used to price petroleum products based & \\
\hline & $\begin{array}{l}\text { on factors such as: reference product cost, } \\
\text { operational costs and cooperate margins, tax }\end{array}$ & \\
\hline & and subsidy, etc. & \\
\hline & $\begin{array}{l}\text { Actually, APM used to determine sale tax } \\
\text { exemption or subsidy needed to cover the gap } \\
\text { between a fixed retail price and the market } \\
\text { price (IISD, 2013). }\end{array}$ & \\
\hline \multirow{3}{*}{ 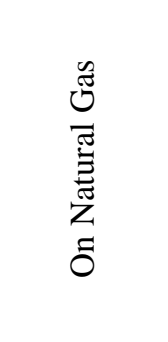 } & $\begin{array}{l}\text { Provided by PETRONAS, Malaysia's state- } \\
\text { owned oil and gas company }\end{array}$ & \multirow{3}{*}{$\begin{array}{l}\text { PETRONAS's foregone revenue in } 2010 \text { was } \\
\text { estimated to be: } \\
\text { - RM } 11.2 \text { billion for gas to power sector } \\
\text { - RM } 7.9 \text { billion for gas to non-power sectors } \\
\text { (Ilias et al., 2012) }\end{array}$} \\
\hline & $\begin{array}{l}\text { To power generators at around } 1 / 4 \text { of the } \\
\text { market price }\end{array}$ & \\
\hline & $\begin{array}{l}\text { To industries and commercial sector at heavily } \\
\text { subsided prices as well, but lesser than to } \\
\text { power generators }\end{array}$ & \\
\hline \multirow{7}{*}{$\frac{\mathscr{D}}{\sum_{0}^{0}}$} & \multirow{3}{*}{$\begin{array}{l}\text { In May 2010, Subsidy Rationalization } \\
\text { Programme (SRP) was launched, aiming to } \\
\text { increase the prices of subsidized commodities } \\
\text { including petroleum products by pre-specified } \\
\text { amounts every } 6 \text { months until } 2014\end{array}$} & Most price adjustments did not take place \\
\hline & & Suspended in March \\
\hline & & $\begin{array}{l}\text { Government's concern on cost of living due to } \\
\text { rising commodity prices (Teoh, 2012) }\end{array}$ \\
\hline & \multirow{3}{*}{$\begin{array}{l}\text { In September 2013, an ad hoc increase in the } \\
\text { price of diesel and petrol, the first adjustment } \\
\text { since } 2011\end{array}$} & No reform made to the APM. \\
\hline & & $\begin{array}{l}\text { Compensate the poor through extended } \\
\text { 1Malaysia People's Aid (BR1M) program }\end{array}$ \\
\hline & & $\begin{array}{l}\text { Upgrade database system for previous welfare } \\
\text { assistance program }\end{array}$ \\
\hline & $\begin{array}{l}\text { At the end of 2014, subsidies for gasoline and } \\
\text { diesel removed (Adam and Pakiam, 2014) }\end{array}$ & $\begin{array}{l}\text { Possible due to diminished gap between } \\
\text { reference prices and market price due to the } \\
\text { low oil price }\end{array}$ \\
\hline
\end{tabular}


Table 2. Scenario assumptions

\begin{tabular}{|c|c|c|c|c|}
\hline & & & \multicolumn{2}{|c|}{ Fiscal Expenditure } \\
\hline & & & Fixed & Floating \\
\hline Scenario 1. & No petroleum subsidies & & $1 a$ & $1 b$ \\
\hline \multirow[t]{2}{*}{ Scenario 2.} & No gas subsidy & Power only $(P)$ & $2 a \_P$ & $2 b_{-} P$ \\
\hline & & Power, Industries \& Commercial $(P I C)$ & $2 a_{-} P I C$ & $2 b \_P I C$ \\
\hline \multirow[t]{2}{*}{ Scenario 3.} & \multirow{2}{*}{$\begin{array}{l}\text { No petroleum \& gas } \\
\text { subsidies }\end{array}$} & Power only $(P)$ & $3 a \_P$ & $3 b \_P$ \\
\hline & & Power, Industries \& Commercial (PIC) & 3a_PIC & $3 b \_P I C$ \\
\hline
\end{tabular}

Table 3. Macro impacts with fixed fiscal expenditure in $\%$

\begin{tabular}{|c|c|c|c|c|c|}
\hline & \multirow[t]{2}{*}{$1 a$} & \multicolumn{2}{|r|}{$2 a$} & \multicolumn{2}{|r|}{$3 a$} \\
\hline & & $P$ & PIC & $P$ & $P I C$ \\
\hline GDP & 0.07 & 0.28 & 0.53 & 0.38 & 0.65 \\
\hline Exports & 1.01 & -0.53 & -0.72 & 0.43 & 0.21 \\
\hline Budget deficit & -28.2 & -3.92 & -7.84 & -31.7 & -35.0 \\
\hline $\mathrm{CO}_{2}$ emissions & -1.84 & -4.64 & -4.22 & -6.37 & -5.90 \\
\hline H1 consumption & -1.13 & -0.25 & -0.01 & -1.32 & -1.02 \\
\hline $\mathrm{H} 2$ consumption & -1.25 & -0.09 & 0.21 & -1.27 & -0.92 \\
\hline H3 consumption & -1.42 & 0.08 & 0.48 & -1.25 & -0.79 \\
\hline H4 consumption & -1.61 & 0.23 & 0.73 & -1.28 & -0.71 \\
\hline
\end{tabular}

Table 4. Impacts on sectoral output with fixed fiscal expenditure in \%

\begin{tabular}{lr|rr|rr}
\hline & $\boldsymbol{1 a}$ & $\boldsymbol{2 a}$ & $\boldsymbol{3 a}$ \\
& & $\boldsymbol{P}$ & $\boldsymbol{P I C}$ & $\boldsymbol{P}$ & $\boldsymbol{P I C}$ \\
\hline Agriculture & -1.37 & 0.89 & 0.61 & -0.38 & -0.59 \\
Food \& Wear & -1.76 & 1.13 & -0.15 & -0.52 & -1.71 \\
Wood \& Paper & -0.45 & -0.74 & -0.43 & -1.09 & -0.77 \\
Chemicals \& Metal & -2.48 & -0.71 & -6.27 & -2.97 & -8.09 \\
Machinery & 3.77 & -2.82 & -1.89 & 0.62 & 1.24 \\
Vehicles & 1.05 & 0.29 & -0.21 & 1.38 & 0.87 \\
Construction & 1.99 & 0.72 & 0.85 & 2.71 & 2.82 \\
Wholesale \& Retail Trade & -0.90 & 0.56 & 0.86 & -0.28 & 0.07 \\
Hotel \& Restaurant & -1.08 & -0.20 & 0.15 & -1.21 & -0.82 \\
Transport & -4.57 & 1.30 & 2.59 & -3.20 & -1.90 \\
Communications \& Amusement & -0.50 & -0.25 & 0.54 & -0.73 & 0.08 \\
Housing & -0.62 & 0.07 & 0.50 & -0.51 & -0.00 \\
Education & -0.46 & 0.06 & 0.24 & -0.38 & -0.17 \\
Health & -0.60 & 0.04 & 0.14 & -0.53 & -0.39 \\
Other Services & -0.15 & -0.32 & 0.04 & -0.45 & -0.09 \\
Electricity & -0.72 & -10.1 & -8.98 & -10.7 & -9.53 \\
\hline
\end{tabular}


Table 5. Macro impacts with floating fiscal expenditure in $\%$

\begin{tabular}{lr|rr|rr}
\hline & $\boldsymbol{1 b}$ & & $\boldsymbol{2 b}$ & & $\mathbf{3 b}$ \\
& & $\boldsymbol{P}$ & $\boldsymbol{P I C}$ & $\boldsymbol{P}$ & $\boldsymbol{P I C}$ \\
\hline GDP & 0.04 & 0.28 & 0.53 & 0.35 & 0.61 \\
Exports & -0.28 & -0.64 & -1.00 & -0.93 & -1.28 \\
Budget deficit & -0.53 & 0.63 & 1.11 & 0.15 & 0.65 \\
Government consumption & 8.19 & 0.82 & 1.73 & 8.80 & 9.50 \\
$\mathrm{CO}_{2}$ emissions & -2.09 & -4.67 & -4.27 & -6.63 & -6.17 \\
$\mathrm{H}$ consumption & -0.99 & -0.24 & 0.02 & -1.16 & -0.86 \\
$\mathrm{H} 2$ consumption & -1.11 & -0.08 & 0.23 & -1.11 & -0.76 \\
$\mathrm{H} 3$ consumption & -1.34 & 0.09 & 0.50 & -1.16 & -0.70 \\
$\mathrm{H} 4$ consumption & -1.70 & 0.22 & 0.71 & -1.37 & -0.82 \\
\hline
\end{tabular}

Table 6. Impacts on sectoral output with floating fiscal expenditure in $\%$

\begin{tabular}{|c|c|c|c|c|c|}
\hline \multicolumn{2}{|r|}{$1 b$} & \multicolumn{2}{|r|}{$2 b$} & \multicolumn{2}{|r|}{$3 b$} \\
\hline & & $\boldsymbol{P}$ & PIC & $\boldsymbol{P}$ & $P I C$ \\
\hline Agriculture & -1.96 & 0.83 & 0.48 & -1.03 & -1.30 \\
\hline Food \& Wear & -2.21 & 1.09 & -0.26 & -1.02 & -2.26 \\
\hline Wood \& Paper & -1.58 & -0.86 & -0.67 & -2.31 & -2.09 \\
\hline Chemicals \& Metal & -4.29 & -0.88 & -6.65 & -4.88 & -10.1 \\
\hline Machinery & 1.57 & -3.00 & -2.34 & -1.67 & -1.31 \\
\hline Vehicles & -1.88 & 0.00 & -0.82 & -1.77 & -2.50 \\
\hline Construction & -1.40 & 0.38 & 0.13 & -0.94 & -1.12 \\
\hline Wholesale \& Retail Trade & -1.92 & 0.46 & 0.63 & -1.39 & -1.14 \\
\hline Hotel \& Restaurant & -0.83 & -0.18 & 0.20 & -0.95 & -0.54 \\
\hline Transport & -4.92 & 1.26 & 2.51 & -3.57 & -2.31 \\
\hline Communications \& Amusement & -0.17 & -0.22 & 0.61 & -0.38 & 0.45 \\
\hline Housing & -0.24 & 0.10 & 0.58 & -0.11 & 0.38 \\
\hline Education & 3.89 & 0.59 & 1.25 & 4.41 & 4.96 \\
\hline Health & 2.68 & 0.47 & 0.74 & 3.12 & 3.32 \\
\hline Other Services & 2.31 & -0.12 & 0.55 & 2.13 & 2.76 \\
\hline Electricity & -0.58 & -10.1 & -8.95 & -10.5 & -9.36 \\
\hline
\end{tabular}


Table 7. Compensating variation (CV) and equivalent variation (EV) in Billion RM

\begin{tabular}{|c|c|c|c|c|c|}
\hline \multirow{3}{*}{$1 a$} & & H1 & $\mathrm{H} 2$ & $\mathrm{H3}$ & H4 \\
\hline & $\mathrm{CV}$ & -0.22 & -1.27 & -2.05 & -2.57 \\
\hline & EV & -0.22 & -1.25 & -2.02 & -2.52 \\
\hline \multirow[t]{2}{*}{$1 b$} & $\mathrm{CV}$ & -0.20 & -1.12 & -1.92 & -2.70 \\
\hline & EV & -0.19 & -1.11 & -1.91 & -2.67 \\
\hline \multirow[t]{2}{*}{$2 a \_P$} & $\mathrm{CV}$ & -0.05 & $\begin{array}{l}-0.09 \\
\end{array}$ & 0.12 & 0.37 \\
\hline & EV & -0.05 & -0.09 & 0.12 & 0.37 \\
\hline \multirow[t]{2}{*}{$2 a \_P I C$} & $\mathrm{CV}$ & 0.00 & 0.21 & 0.69 & 1.16 \\
\hline & EV & 0.00 & 0.21 & 0.68 & 1.15 \\
\hline \multirow[t]{2}{*}{$2 b \_P$} & $\mathrm{CV}$ & -0.05 & -0.08 & 0.13 & 0.35 \\
\hline & EV & -0.05 & -0.08 & 0.13 & 0.35 \\
\hline \multirow[t]{2}{*}{$2 b \_P I C$} & $\mathrm{CV}$ & 0.00 & 0.24 & 0.71 & 1.12 \\
\hline & EV & 0.00 & 0.23 & 0.71 & 1.12 \\
\hline \multirow[t]{2}{*}{$3 a \_P$} & $\mathrm{CV}$ & -0.26 & -1.29 & -1.82 & -2.05 \\
\hline & EV & -0.26 & -1.27 & -1.79 & -2.01 \\
\hline \multirow[t]{2}{*}{ 3a_PIC } & $\mathrm{CV}$ & -0.20 & -0.93 & -1.15 & -1.13 \\
\hline & EV & -0.20 & -0.92 & -1.13 & -1.11 \\
\hline \multirow[t]{2}{*}{$3 b \_P$} & $\mathrm{CV}$ & -0.23 & -1.12 & -1.67 & -2.18 \\
\hline & EV & -0.23 & -1.11 & -1.65 & -2.15 \\
\hline \multirow[t]{2}{*}{$3 b \_P I C$} & $\mathrm{CV}$ & -0.17 & -0.76 & -1.01 & -1.30 \\
\hline & EV & -0.17 & -0.76 & -1.00 & -1.29 \\
\hline
\end{tabular}

Table 8. Macro impacts with direct government transfer to the lowest income households (H1) in $\%$

\begin{tabular}{lr|r|rr|r|rr|rr}
\hline & $\boldsymbol{1 a}$ & $\mathbf{1 b}$ & $\boldsymbol{2 a}$ & $\mathbf{2 b}$ & $\mathbf{3 a}$ & $\mathbf{3 b}$ \\
& & & $\boldsymbol{P}$ & $\boldsymbol{P I C}$ & $\boldsymbol{P}$ & $\boldsymbol{P}$ & $\boldsymbol{P I C}$ & $\boldsymbol{P}$ & $\boldsymbol{P I C}$ \\
\hline GDP & 0.07 & 0.04 & 0.28 & 0.53 & 0.28 & 0.38 & 0.65 & 0.35 & 0.61 \\
Exports & 0.99 & -0.27 & -0.54 & & -0.64 & 0.40 & 0.19 & -0.92 & -1.28 \\
Budget deficit & -27.5 & -0.53 & -3.77 & -7.84 & 0.63 & -30.9 & -34.4 & 0.14 & 0.65 \\
Government consumption & - & 8.01 & - & - & 0.77 & - & - & 8.59 & 9.35 \\
$\mathrm{CO}_{2}$ emissions & -1.84 & -2.08 & -4.64 & & -4.66 & -6.37 & -5.89 & -6.62 & -6.17 \\
$\mathrm{H}$ c consumption & - & - & - & - & - & - & - & - & - \\
$\mathrm{H} 2$ consumption & -1.26 & -1.12 & -0.09 & 0.21 & -0.08 & -1.27 & -0.92 & -1.12 & -0.76 \\
$\mathrm{H}$ consumption & -1.42 & -1.34 & 0.08 & 0.48 & 0.09 & -1.25 & -0.79 & -1.16 & -0.70 \\
$\mathrm{H} 4$ consumption & -1.61 & -1.70 & 0.23 & 0.73 & 0.22 & -1.28 & -0.71 & -1.37 & -0.82 \\
\hline
\end{tabular}

